\section{NÉHÁNY GYAKORLATI TAPASZTALAT A BIZTOSÍTÓI ESZKÖZ-FORRÁS MENEDZSMENTBEN}

Pásztor Gábor (matematikus, aktuárius szakértö, Aegon Magyarország Általános Biztositó Zrt., vezető kockázatkezelö), pasztorgabor@aegon.hu -Zsigri Gábor (matematikus, aktuárius szakértö, Aegon Magyarország Általános Biztositó Zrt., vezetöaktuárius), zsigri.gabor@aegon.hu

\section{ÖSSZEFOGLALÓ}

A biztosítók eszköz-forrás menedzsment (ALM) vizsgálataiban Magyarországon még nincs kialakult alkalmazandó gyakorlat, viszont sok olyan téves megközelítéssel vagy módszertanok helytelen alkalmazásával találkoztunk például a pénzáramlás meghatározásában, vagy duration formulák használatában, fóként a többlethozam-visszaadásos életbiztosítások esetében, amelyeket érdemes részletesebben körüljárni, hogy elkerülhetők legyenek az ezekből fakadó esetleges téves üzleti döntések. Cikkünkben igyekszünk összegyűjteni az eszközforrás menedzsment céljait, a célok közötti ellentmondásokat, a különböző célok esetében használandó alapadatokat, módszereket. Néhány egyszerüsített biztosítási példán keresztül bemutatjuk a gyakorlati alkalmazást.

A szerzők köszönik Horváth Gyula és Perger Balázs szakmai észrevételeit.

\section{SUMMARY}

There is no common practice in Asset Liability Management (ALM) of Hungarian insurance companies, but we met many inaccurate approach or misapplications of methodologies for examples in definition of cash-flow or applications of different type of duration formulas mainly in case of profit share life insurance portfolios that worth walking around in detail to avoid any incorrect business decisions arising from them. In this paper we try to collect the objectives of Asset Liability Management, contradictions between the objectives, input data and methods should be applied in case of different goals. Through some simplified insurance example we describe the practical application.

Kulcsszavak: tartalék, befektetés, likviditás, ALM, átlagidő (duration)

Key words: reserve, investment, liqidity, ALM, duration

JEL: G11, G22

DOI: $10.18530 /$ BK.2017.1.58

http://dx.doi.org/1018530/BK.2017.1.58

\section{Bevezetés}

A biztosítási szerződésekhez kapcsolódó eszköz-forrás menedzsment felveti, hogy ne csak a jelen pillanatban legyen megfelelö az egyensúly az eszközök és források között, hanem foglalkozzunk azzal is, hogy a jövőben se fussunk bele ebből fakadó problémába. Mielőtt belekezdenénk a problémás esetek bemutatásába, fontosnak éreztük azon alapvető megfontolások ismertetését, melyekkel az ALM tevékenységek során rendszeresen szembesülünk.

1. cél:

Eltérő megközelítésekkel, de a szakértők mindenekelőtt a jövőbeli likviditási követelményeket szokták megemlíteni. A biztosítási szerződésekből eredő, jövőben megvalósuló és egész jól becsülhető (legalábbis most ezt feltételezzük) várható pénzmozgások esetében szerencsés, ha nem jelent akadályt az, hogy az akkor éppen meglévő pénzügyi eszközök közt nincs megfelelő mennyiségű pénzzé alakítható állomány. Lehetséges, hogy a meglévő kötvényállomány ${ }^{1}$ lejárati struktúrája túl hosszú, és már most látható, hogy ez likviditási gondot fog jelenteni a jövőben. Ha pedig lejárat előtt kell megválnunk bizonyos kötvényektől, akkor emiatt jelentős realizálási veszteségeket (vagy nyereséget) ${ }^{2}$ szenvedhetünk el. Ha nem akarjuk vállalni a kötvények lejárat előtt történő eladásából eredő realizálási veszteség/nyereség bizonytalanságából vagy esetleges illikviditásból fakadó kockázatot, akkor igyekezni kell, hogy a meglévő pénzügyi eszközök lejárati struktúrája lehetőleg ne nyúljon jelentősen túl a kötelezettségek lejárati struktúráján.

Ugyanez fordítva is problémát jelenthet. Ha a kötvények jóval hamarabb lejárnak, mint ahogy a biztosítóknak kifelé (külső partnerek, ügyfelek felé) ténylegesen kifizetéseket kellene teljesíteniük, akkor a jövőben újra be kell fektetniük az idő előtt felszabaduló pénzt, és az, hogy a jövőben milyen kondíciókkal lehet majd befektetni, nem tudható előre, emiatt újra-befektetési kockázatot fut a biztosító.

A megoldás a két irány között a pontos illesztés lehet, a befektetési környezet azonban gyakran nem kínál olyan részletes lejárati struktúra lehetőségeket, mint amilyenre a biztosító kötelezettségei alapján szükség lenne. Emiatt csak közelítő megoldásokat lehet találni.

\section{2. cél:}

Az életbiztosítások tekintetében gyakran fordul elö, hogy a matematikai tartalékokon elérhető hozamra a biztosító minimumgaranciát vállal, és a tartalékok csak ezekkel a minimálisan bevállalt jövőbeli kamatokkal együtt tudnak elegendő fedezetet biztosítani a várható kifizetésekre. A jövőre vonatkozó reális ígéretekben vállalt kamatgaranciák bizonyos esetekben előre biztosíthatóak megfelelő kamatozású és lejáratú értékpapírok vásárlásával. Ezek megvásárlása ugyan eliminálhatja a kamatkörnyezet jövőbeni esetleges csökkenéséből fakadó kamathiány kockázatát, de egyúttal el is esünk az esetleges jövőbeni 
kamatemelkedésből nyerhető extra kamatbevételektől. Nyilván ebben is megfelelő egyensúlyt kell keresni. A garancia biztosítása során oda kell figyelni arra is, hogy a szerződés teljes tartamára egyetlen garancia van csupán, vagy minden egyes év esetében folyamatosan biztosítani kell egy hozamgaranciát. A korábbi jogszabályok miatt a mai magyar életbiztosítási szerződések elsöprő többsége ezt az utóbbi hozamgaranciát tartalmazza.

\section{3. cél:}

Végül, de nem utolsósorban az eszköz-forrás menedzsment egyik legfontosabb célja a kamatláb-érzékenység csökkentése. A legtöbb, általunk hibásnak vélt megközelítéssel ebben a témakörben találkoztunk. A biztosító piaci értéke a kamatkörnyezet alakulásától függően változhat. A kamatkörnyezet változására a mérleg eszközoldala eltérő módon változhat a kötelezettségekhez viszonyítva. Célszerű emiatt vizsgálni mind az eszközök, mind a kötelezettségek piaci értékének kamatláb-érzékenységét, és amennyiben lehetséges, úgy kialakítani mindkettő struktúráját, hogy egyszerre mozogjanak, vagyis ezzel minimalizáljuk a kamatok esetleges megváltozása miatt bekövetkező vállalati piaci érték változását. Az ingadozó kamatkörnyezetben stabilabb piaci értéket mutató vállalatok a részvénypiacokon pozitívabb megítélés alá eshetnek.

\section{A különböző célok kapcsolódása}

Ha az első likviditási célt pontosan sikerül illesztenünk megfelelő hozammal rendelkező kötvényekkel, akkor az rendszerint egyúttal biztosítja a 2. kamatgarancia-célt, és minimalizálja a kamatláb-érzékenységet is, vagyis a 3. célt. Viszont a másik két cél esetében ez nem feltétlenül igaz. Ha találunk megfelelő kamatokat eredményező kötvényeket, még messze nem biztos, hogy likviditási szempontból is megfelelőek lesznek, és legtöbbször nem az optimális kamatláb-érzékenységet biztosítják. Ha találunk olyan kötvényeket, melyekkel a vállalat piaci értéke a kamatok változására kevésbé érzékeny, akkor ez egyáltalán nem garantálja a megfelelő hozamokat vagy a szükséges likviditást. Cikkünkben igyekszünk bemutatni, hogy milyen veszélyeket rejt az olyan eszköz-forrás illesztési gyakorlat az optimalizálás során, mely pusztán a kamatláb-érzékenység csökkentésére törekszik, és megfeledkezik arról, hogy a másik két cél így nem feltétlenül teljesül. Bemutatjuk azt is, hogy mely célok, milyen indikátorokkal optimalizálhatók, és ha ezeket helytelenül alkalmazzuk, az akár téves üzleti döntésekhez is vezethet.

\section{Likviditás új szerzés figyelembevételével vagy új szerzés figyelembevétele nélkiii}

A likviditás biztosítása során el kell dönteni, hogy milyen üzemmenet biztosítása a cél. Egy folyamatosan működő, új szerzésekkel folyamatosan bővülő vállalat ugyanis teljesen más likviditási stratégiát igényel egy olyan vállalattal szemben, mely már nem bővül új szerzésekkel, pusztán a meglévő portfólió kifutásához szükséges likviditást kell biztosítani. Természetesen az is lehet cél, hogy bármikor készek legyünk egy kifutó portfólióra átálló vállalat likviditásának biztosítására, miközben folyamatosan bővül a vállalat új szerzésekkel, emiatt folyamatosan frissíteni kell a korábban kialakított likviditási stratégiát. Amennyiben így járunk el, akkor megkötjük a saját kezünket, és megfosztjuk magunkat egy sokkal előnyösebb hozamokkal bíró eszközstratégia kialakításának a lehetőségétől. Hiszen ha folyamatosan bővül a biztosító tartalékállománya, lényegében soha sem kell a tartalékportfóliók mögé helyezett kötvények lejárati pénzáramaira számítani, vagyis a folyamatos bevételekből folyamatosan biztosítható a kiadások pénzárama, akkor feleslegesen „tömjük tele” a tartalékportfóliókat egy esetleges új értékesítés bezárása miatt szükséges, rövidebb lejáratú papírok tömegével, rendszerint alacsonyabb hozamokat elérve emiatt. Ebben a kérdésben el kell döntenie a vállalatnak, hogy mire optimalizál. A gyakorlat meglehetősen óvatos: a sokkal kisebb valószínűséggel bekövetkező kifutó portfólió likviditását szokás illeszteni. Így ugyan jelentősen szűkítjük a befektetési lehetőségeket, viszont sokkal biztonságosabb a gyakorlat. A Felügyelet szempontjából is jogos lehet ilyen követelmény elvárása, ugyanis ha egy biztosító bármilyen okból felfüggeszti értékesítési tevékenységét, és a biztosító a likviditását az új szerzéssel együtt optimalizálta, akkor az új szerzés felfüggesztése egyúttal likviditási krízishelyzetet is okozhatna a vállalatnál. A legkörültekintőbbek akkor vagyunk, ha elvégezzük a vizsgálatot kifutó portfólió feltételezéssel is, valamint megvizsgáljuk azt is, hogy mi várható néhány évnyi további új szerzés figyelembevétele esetén.

\section{Pénzáramlás (cash-flow, $\mathrm{CF}$ ) definiálása}

Ez a lépés első megközelítésben nem tűnik nehéznek, hiszen a jövőben várható pénzáramlást manapság számos helyen meg kell becsülni, többek között a tartalékok kiszámításához vagy tőkeszámításokhoz. Rögtön az elején, már a pénzáramlás definiálásánál beleeshetünk az első hibába, amivel a gyakorlatban gyakran találkozhatunk. Mellőzve a tényleges pénzügyi folyamatok átgondolását, azt hisszük, hogy az ALM vizsgálatok során ugyanazokat a pénzáramlásokat kell pusztán használnunk, mint amelyeket a tartalékszámítások esetében. Ez sajnos nem feltétlenül igaz. A tartalékszámításhoz használt pénzáramlás (1) szerint:

$(\mathrm{CF})=($ díjbevétel $)-($ szolgáltatások $)-\left(\right.$ költségek $\left.{ }^{3}\right)$

Az eszköz-forrás illesztés során a különböző termékek tartalékai mögé fedezetként rendelt eszközök pénzmozgásait igyekszünk szinkronba hozni a kötelezettségek pénzáramlásaival, megteremtve ezzel a folyamatok azon egyensúlyát, melyben az eszközök oldaláról pontosan akkor és pontosan annyi pénz szabadul fel, mint amikor és amennyi pénzre a kötelezettségeink teljesítéséhez szükségünk van. Vizsgáljuk meg, hogy a valóságban mi is történik! A biztosítónak definiálnia kell egy eszközportfóliót, melynek célja bizonyos tartalékok eszközfedezetének biztosítása. A biztosítónak az eszközök kezelője felé folya- 
matosan instrukciókat kell adnia, hogy az adott termékekhez tartozó tartalékok mögé mekkora eszközmennyiséget kell rendelni. Ezt nyilván csak úgy teheti meg, hogy időről időre az aktuáriusoktól érkező tartalékszámítás eredményét átadja az eszközkezelőnek, és ennek alapján az eszközkezelő az eszközportfóliót valamilyen eszközérték-mutató alapián hozzáigazítja a kívánt tartalékmennyiséghez. Ha több eszköz volt eredetileg a portfólióban, mint amennyi tartalékszükségletet az aktuáriusoktól kapott, akkor elad az eszközökből, ha pedig kevesebb, akkor vásárol továbbiakat. Ebben az előző mondatban vázoltuk fel a tényleges ALM szempontjából figyelembe veendő kötelezettségek miatt az eszközöktől elvárt pénzáramlást. Hiszen amikor az eszközkezelő eladott értékpapírt, az pénzt generált, amikor pedig vásárolt, akkor pénzt fogyasztott $\mathrm{el}^{4}$. És ez a befektetési folyamatok miatti pénzáramlás jellemzően a tartalékok változásából generálódott, ami nem feltétlenül azonos a korábban mutatott pénzáramlással ${ }^{5}$. De nem is tisztán a tartalékok változása adja az eszközportfóliótól megkívánt adott időszakra vonatkozó pénzáramlás mértékét, hiszen az eszközportfólió értéke is változik automatikusan az idő haladtával. Az eszközök kezelőjének a szükséges tartalékváltozásból le kell vonnia a fedezetet biztosító eszközök értékének automatikus változását, és csak ezen különbözet mértéke szerint kell eladnia vagy vásárolnia eszközöket. Tételezzük most fel, hogy az eszközportfólió kötvényekből áll, és az adott időperiódus alatt magára volt hagyva, vagyis se nem adtunk el az eszközök közül, se nem vásároltunk újat. A kötvények értékének (melyet a tartalékok fedése esetében figyelembe veszünk) pedig a lineárisan amortizált bruttó értékét használjuk (2)-ben, vagyis

(fedő érték $)=($ könyv szerinti érték $)+($ felhalmozott kötvényamortizáció) $+($ kupon tartalék $)$

ahol:

- a könyv szerinti érték a kötvények nettó beszerzési értéke ${ }^{6}$, vagy ha valamelyik kötvény esetében történt a beszerzés óta leértékelés, akkor az utolsó leértékelt érték,

- a felhalmozott kötvényamortizáció a beszerzési nettó érték (vagy utolsó leértékelt érték) és a lejárati névérték közötti különbség lineáris időarányos része, adott időszaki kötvényamortizáció alatt pedig a felhalmozott kötvényamortizáció változását értjük,

- a kupontartalék pedig az utolsó kuponfizetés és a következő kuponfizetés közötti időarányosan már megszolgált része a következő kuponfizetésnek. Szokás felhalmozott vagy elhatárolt kamatnak is nevezni. Minden egyes kuponfizetéskor a kupontartalék visszaesik nullára, majd az idő haladtával lineárisan felkúszik a következő kupon mértékéig.

A kötvény adott időszaki hozamát (3) szerint határozzuk meg:

\section{A fedő érték időszaki változása így a (4)-beli elemekből áll:}

(fedő érték változása) $=$

= - (lejárt kötvények névértéke) + (időszaki kötvényamortizáció) + (kupontartalék változása)

Ha a kuponfizetést beemeljük a fenti egyenletbe, akkor (5) alapján (6) adódik:

(fedő érték változása) $=-$ (lejárt kötvények névértéke $)-($ kuponfizetések $)+($ időszaki kötvényamortizáció) + (kupontartalék változása) + (kuponfizetések $)=$ - (lejárt kötvények névértéke) - (kuponfizetések) + (a kötvények hozama)

vagyis

(fedó érték változása $)$ = - (kötvények cash-flow-ja) + (kötvények hozama)

Ha minden a feltételezéseink szerint történik - és korábban tökéletes eszköz-forrás illesztést végeztünk -, továbbá az eszközök portfólióját úgy alakítottuk ki, hogy azok automatikus pénzáramlása (lejáratok, kuponfizetések) pontosan megegyezik a tartalékok kifutásával, vagyis az eszközök kezelőjének (ami sokszor maga a biztosító) sohasem kell semmit igazítania (vásárolnia vagy eladnia) az eszközportfólión, pusztán az időközben keletkező készpénzeket kell egyszerűen kivezetni a portfólióból, így az mindig automatikusan a kívánt mértékre változik, akkor (7)-ből felírható (8):

(tartalékok változása $)=($ fedő érték változása $)$

azaz

(tartalékok változása $)=-($ kötvények cash-flow-ja $)+($ kötvények hozama $)$

ezt átrendezve (9) adódik:

(kötvények cash-flow-ja) = (kötvények hozama) - (tartalékok változása)

Ez az a képlet, amely megmutatja, hogy milyen pénzáramlást kell a kötvényeknek generálniuk tökéletes tartalékkifutás-illesztés esetében. Ennek a (10) képletnek a jobb oldalát a későbbiekben tartalék cash-flow-nak fogjuk hívni, hogy megkülönböztessük a hagyományosan definiált cash-flow fogalmától.

(tartalék cash-flow) = - (tartalékok változása) + (kötvények hozama) 
Amennyiben nem bruttó lineárisan amortizált kötvényértéket, hanem a kötvények bruttó piaci értékét használjuk a tartalékok fedéséhez, ugyanerre az eredményre jutunk:

(fedó érték $)=($ bruttó piaci érték $)=($ nettó piaci érték $)+($ kupontartalék $)$

$($ hozam $)=($ kuponfizetés $)+($ kupontartalék változása $)+($ nettó piaci érték változása $)$

(fedő érték változása $)=-$ (lejárt kötvények névértéke) + (nettó piaci érték változása $)+($ kupontartalék változása $)=-$ (lejárt kötvények névértéke $)-($ kuponfizetések $)+$ (nettó piaci érték változása $)$ + (kupontartalék változása) + (kuponfizetések $)=-$ (lejárt kötvények névértéke) - (kuponfizetések $)$ + (a kötvények hozama) $=-$ (kötvények cash-flow-ja $)+($ kötvények hozama $)$

Tökéletes illesztés esetében:

(tartalékok változása) = (fedő érték változása)

(tartalékok változása $)$ - (kötvények cash-flow-ja $)+($ kötvények hozama $)$

ezt átrendezve:

(kötvények cash-flow-ja) = (kötvények hozama) - (tartalékok változása)

(tartalék cash-flow) $=$ - (tartalékok változása $)+($ kötvények hozama $)$

A tartalék cash-flow egy vállalaton belüli pénzáramlás, ami ténylegesen megjelenik a befektetéskezelés során. Ha az eszköz kezelőjének kötvényt kell vásárolnia, hogy kipótolja a tartalékfedő portfóliót, akkor ezen kötvény vásárlásához megfelelő mennyiségű készpénzzel kell rendelkeznie a vállalatnak, és fordítva, ha el kell adnia a tartalékot fedő portfólióból, hogy lecsökkentse a portfóliót a megfelelő mértékűre, akkor ténylegesen pénzbevétele származik a kötvény eladásából. A legnagyobb tanulság ebből, hogy nemcsak az okozhat likviditási gondot egy vállalat működésében, ha nem elég likvid az ügyfelek felé történő szolgáltatások tekintetében, hanem komoly belső likviditási gondok fakadhatnak abból, ha nem rendelkezik megfelelő készpénzmennyiséggel, hogy végrehajthassa a tartalékfedő portfóliók szükséges igazítását. Ezen igazításokhoz szükséges készpénzek a tartalékfedő portfólión kívüli eszközök részből származik ${ }^{8}$. A vállalaton belüli tartalékfedő portfóliókon kívüli eszközök összességét maradék portfóliónak fogjuk hívni.

- A maradék portfólió biztosítja, hogy az eszközkezelőnek a szükséges kötvényvásárlásokhoz a megfelelő pénzeszköz mindig rendelkezésére álljon.
- A maradék portfólióba sorolódik át automatikusan a kötvények cash-flow-ja (lejárati összegek, kuponok).

- A maradék portfólióba sorolódik át a kötvények eladási értéke készpénz formájában, ha a kötvényeket lejárat elött kell eladnunk.

- De a maradék portfólió biztosítja a hagyományos értelemben definiált cash-flow-t, vagyis a díjbevételek, szolgáltatások, költségek egyenlegét is,

- és ezen maradék portfólió az, amiből az osztalékok kifizetésre kerülnek, vagy amibe az esetleges tulajdonosi tőketöltések befolynak

Tehát az eszköz-forrás menedzsment során nem elég elvégeznünk a tartalékfedő eszközportfóliók várható pénzáramlásának likviditási illesztését a tartalék cash-flow-kkal, de ugyanezt el kell végeznünk a maradék portfólió esetében is. Meg kell tehát tervezni ennek a maradék portfóliónak is a várható pénzáramlásait, és megfelelő likviditási struktúra alapján ebben a portfólióban is megfelelő eszközstruktúrát kell kialakítani.

A vállalaton belüli eszközportfóliókat és az azokhoz tartozó pénzmozgásokat az 1. ábra szemlélteti:

1. ábra: Egyszerüsített eszközportfólió struktúra és a pénzmozgások

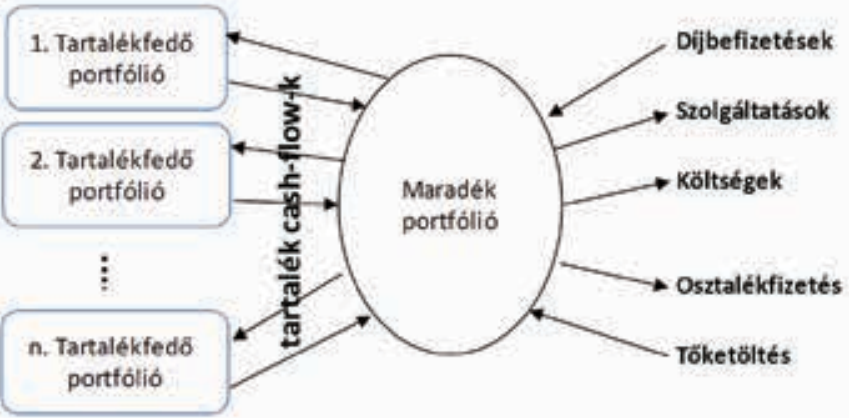

Forrás: Saját szerkesztés

A tartalékfedő portfóliók legtöbbször termékenként, termékcsoportonként vagy üzletáganként kialakított eszközportfóliók. De nem szabad elfeledkezni arról sem, hogy rendszerint egy terméken belül a matematikai tartalék és például a függőkártartalék különböző tartalékfedő portfóliókba vannak sorolva, hiszen a matematikai tartalékra jellemzően alkalmazandó a kamatgarancia, illetve hozamvisszaadás, míg a függőkártartalékra nem. Gyakran találkozunk olyan gyakorlattal, hogy egy termékcsoport matematikai tartalékait a garantált kamat szerint vonják össze csoportokká. Gyakori, hogy az ALM vizsgálatokat csak a matematikai tartalékot fedő eszközportfólióra végzik el. Ha ebben az esetben a kötelezettségek pénzmozgásaira a hagyományos (díj-szolgáltatás-költség) cash-flow-t használjuk, akkor 
a 2. ábrából világosan látható, hogy hibásan járunk el, hiszen ahhoz a pénzmozgáshoz nem a matematikai tartalékot fedő eszközportfóliójának eszköz pénzmozgása tartozik, hanem a termékcsoport valamennyi tartalékfajtájához tartozó fedő eszközportfólió, valamint a termékcsoporthoz tartozó maradék eszközportfólió összessége (amennyiben egyáltalán létezik ilyen elkülönítetten).

2. ábra: Eszközportfóliók között egy termékcsoportot érintő elemek

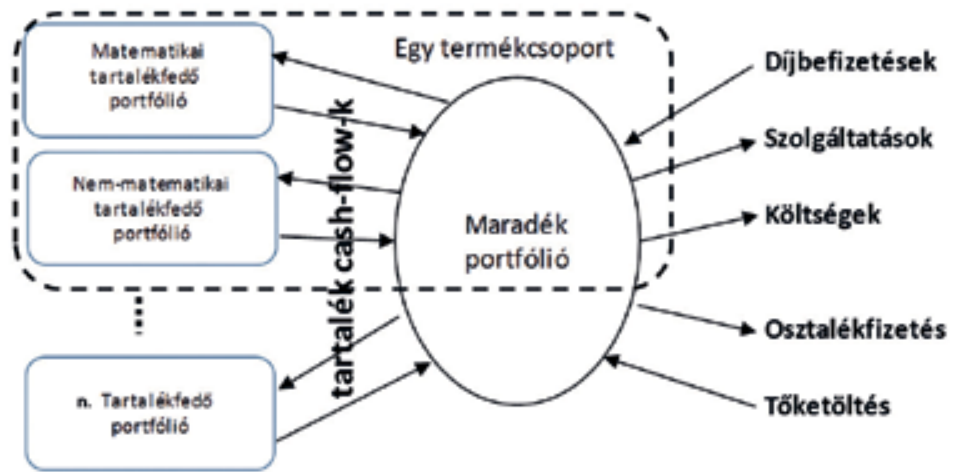

Forrás: Saját szerkesztés

Ha ezeket az eszközportfóliókat összevontan kezeljük, akkor az eszközportfóliók között folyó belső tartalék cash-flow-k kiejtik egymást, eltünnek. Kizárólag a hagyományos (díj-szolgáltatás-költség) pénzmozgás halad át a termékcsoporthoz tartozó eszközök körén (2. ábra szaggatott vonal) kívülre. Vagyis a szaggatott vonalon belül elhelyezkedő eszközök által generált eszköz pénzmozgásnak kellene illeszkednie a hagyományos kötelezettség (liability) cash-flow-hoz. A probléma az, hogy a szaggatott vonalon belüli eszközportfólió a legtöbb biztosító esetében elkülönítetten nem létezik, hiszen a maradék portfólió (saját tőke) a legtöbb biztositó esetében összevontan kezelt ${ }^{9}$, így annak pénzmozgása sem vizsgálható elkülönítetten. Mindebből következik, hogy a hagyományos liability cash-flow használatával elkülönített termékcsoportonkénti ALM vizsgálat helyesen nem végezhetö sem likviditás, sem kamatgarancia, sem kamatláb-érzékenység szempontjából. Amire lehetőség van:

1. A tartalék cash-flow segítségével vizsgálható a tartalékfedő portfóliónkénti cégen belüli pénzmozgás szükséglet belső likviditás szempontjából.

2. A matematikai tartalékokat fedő eszközportfóliók tekintetében vizsgálható a garantált kamatok jövőbeli teljesíthetősége.

3. Hagyományos cash-flow (díj-szolgáltatás-költségek) segítségével jövőbeli likviditás (pl. ügyfelek felé történő szolgáltatási képesség likviditás szempontjából) csak olyan aggregált szinten vizsgálható, amilyen szinten a maradék portfólió meg van bontva. Ez a legtöbb biztosító esetében kizárólag cégösszesen (illetve élet és nem-élet bontásban) vizsgálhatóságot jelent.

4. A piaci értékek kamatláb-érzékenysége vizsgálható ugyan eszközportfóliónként, azonban az eszközök és a kötelezettségek piaci értékének a stabilitása, a kamatok ingadozásának való kitettsége, vagyis a kamatláb-érzékenység a teljes vállalat értékelése szempontjából lényeges, így valamennyi eszközportfólió összevonásával van csak értelme. A belső pénzmozgásoknak ilyenkor nincs jelentőségük.

Önmagában egyik ALM vizsgálat sem elegendő, az ALM tevékenység akkor lehet teljes körü, ha mind a négy felsorolt vizsgálatot magába foglalja ${ }^{10}$.

\section{Duration - két értelemben}

A különböző duration formulák az elmúlt évek során a kelleténél nagyobb hangsúlyt kaptak az ALM vizsgálatok területén. Ráadásul a duration kétféle jelentése (átlagos futamidő, kamatláb-érzékenység), mely gyakran összemosódik, megteremtette a helytelen használatuk lehetőségét is. Meg fogjuk mutatni, hogy ez a kettősség könnyen téves következtetésekhez is vezethet.

\section{A két leggyakrabban használt duration számítási képlete}

A két leggyakrabban előforduló duration a Macaulay Duration és a Módosított (Modified) Duration. A leggyakrabban emlegetett definíciójuk (18) és (19) szerint adható meg:

$$
\begin{gathered}
D_{\text {Mac }}=\frac{\sum_{i=0}^{n} \operatorname{disc}\left(t_{i}\right) \cdot C F_{i} \cdot t_{i}}{\sum_{i=0}^{n} \operatorname{disc}\left(t_{i}\right) \cdot C F_{i}} \\
\left(D_{\text {Mod }}=-\frac{1}{\sum_{i=0}^{n} \operatorname{disc}\left(t_{i}\right) \cdot C F_{i}} \cdot \frac{\partial\left(\sum_{i=0}^{n} \operatorname{disc}\left(t_{i}\right) \cdot C F_{i}\right)}{\partial r}\right.
\end{gathered}
$$

ahol:

$D_{M a c}:$ a Macaulay Duration = átlagidő értéke

$D_{M o d}$ a Módosított Duration = kamatláb-érzékenység értéke,

CF: az i-edik pénzmozgás elem,

$t_{i}$ : az i-edik pénzmozgás elem időpontja,

$\operatorname{disc}(t)$ : a t időponthoz tartozó diszkontszorzó (a kockázatmentes hozamgörbe alapján),

$r$ : a kamat mértéke, mely szerint a Módosított Duration képletében deriválunk. 
A Macaulay Duration képlete beszédes: a cash-flow-fizetési időpontok súlyozott átlaga a diszkontált pénzmozgás értékekkel mint súlyokkal súlyozva. Ez az átlagos futamidőt fejezi ki.

A Módosított Duration pedig a diszkontált pénzmozgás kamat szerinti deriváltja osztva a diszkontált pénzmozgás értékével. Vagyis kifejezi a kamatláb-változási érzékenységet. Úgy is szokták emlegetni, hogy egy százalék kamatelmozdulásra a diszkontált pénzmozgás értéke hány százalékkal változik. A definíció nem egyértelmű, mivel függ a képletben alkalmazott kamat különböző mérőszámaitól (havi kamat, éves kamat, kamatintenzitás, ...), és ettől függően más eredményt ad. Nem mindenhol egyértelmű a definícióból az sem, hogy miként kell értelmezni a képletet és benne a kamatváltozót egy nem konstans kockázatmentes hozamgörbe esetén.

Kapcsolatot jelent a két duration között, hogy minél inkább kisebb időegységekhez tartozó időarányos kamatszorzók hatványozással évesített értékei szerint diszkontálunk, annál közelebbi értéket ad a két duration.

$$
D_{\text {Mad }}=-\frac{1}{\sum_{i=0}^{n} \frac{C F_{i}}{\left[\left(1+\frac{r}{k}\right)^{k}\right]^{t_{i}}}} \cdot \frac{\partial\left(\sum_{i=0}^{n} \frac{C F_{i}}{\left[\left(1+\frac{r}{k}\right)^{k}\right]^{t_{i}}}\right)}{\partial r}=\frac{1}{\left(1+\frac{r}{k}\right)} \cdot \frac{\sum_{i=0}^{n} t_{i} \cdot \frac{C F_{i}}{\left[\left(1+\frac{r}{k}\right)^{k}\right]^{t_{i}}}}{\sum_{i=0}^{n} \frac{C F_{i}}{\left[\left(1+\frac{r}{k}\right)^{k}\right]^{t_{i}}}}=\frac{D_{\text {Mac }}}{\left(1+\frac{r}{k}\right)}
$$

Speciálisan amikor $k=1$ :

$$
D_{\text {Mod }}=\frac{D_{\text {Mac }}}{(1+r)}
$$

Határesetben $(k \rightarrow \infty)$ a Módosított Duration értéke azonos a Macaulay Duration értékével, ha a deriválást és a diszkontálást a kamatintenzitás képletével hajtjuk végre (22)-ben:

$$
D_{\text {Mod }}=-\frac{1}{\sum_{i=0}^{n} C F_{i} \cdot e^{-r \cdot t_{i}}} \cdot \frac{\partial\left(\sum_{i=0}^{n} C F_{i} \cdot e^{-r \cdot t_{i}}\right)}{\partial r}=\frac{\sum_{i=0}^{n} t_{i} \cdot C F_{i} \cdot e^{-r \cdot t_{i}}}{\sum_{i=0}^{n} C F_{i} \cdot e^{-r \cdot t_{i}}}=D_{M a c}
$$

De ez mind csak konstans kockázatmentes hozamgörbe esetén értelmezhető. A gyakorlatban viszont ritkán szembesülünk konstans kockázatmentes hozamgörbével, így definiálnunk kellene a Módosított Durationt tetszőleges hozamgörbe esetén is. Mi a hozamgörbe párhuzamos eltolásával járó megközelítést alkalmazzuk. Még így is két megoldás lehetséges azonban. Eltolhatjuk a spot görbét, vagy eltolhatjuk a forward görbét. Gyakran hallani befektetőktől, hogy mindegy, mert a két megközelítés ugyanarra az eredményre vezet, de ez azért nem teljesen így van. Csupán annyi igaz, hogy a mai kamatkörnyezetben nagyon közeli eredményt adnak, negyedik-ötödik tizedesjegyben vannak csak különbségek.

\section{Spot eltolás:}

r értékek legyenek a megfelelő spot kockázatmentes kamatráták (23)-ban:

$D_{\text {Nodt }}=-\frac{1}{\sum_{i=0}^{n} \frac{C F_{i}}{\left(1+r_{i}\right)^{\tau_{i}}}} \cdot \frac{\partial\left(\sum_{i=0}^{n} \frac{C F_{i}}{\left(1+r_{l}+\varepsilon\right)^{t_{i}}}\right)}{\partial \varepsilon}=\frac{\sum_{i=0}^{n} \frac{t_{i}}{\left(1+r_{i}\right)} \cdot \frac{C F_{i}}{\left(1+r_{i}\right)^{t_{i}}}}{\sum_{i=0}^{n} \frac{C F_{i}}{\left(1+r_{i}\right)^{t_{i}}}}=\frac{\sum_{i=0}^{n} t_{i} \cdot \frac{C F_{i}}{\left(1+r_{i}\right)^{t_{i}}}}{\sum_{i=0}^{n} \frac{C F_{i}}{\left(1+r_{i}\right)^{t_{i}}}}$

ahol $\quad \tilde{t}_{i}=\frac{t_{i}}{\left(1+r_{i}\right)}$

\section{Forward eltolás:}

$t_{i}$ időpontok fussanak végig a hónapokon évesített értékekkel: $\quad 0, \frac{1}{12}, \frac{2}{12}, \frac{3}{12}, \ldots$

Legyenek $f_{i}$ értékek a havi forward ráták évesített értékei (25)-ben, vagyis:

$$
f_{0}=0 \quad f_{i}=\left(\frac{\left(1+r_{i}\right)^{t_{i}}}{\left(1+r_{i-1}\right)^{t_{i-1}}}\right)^{12}
$$

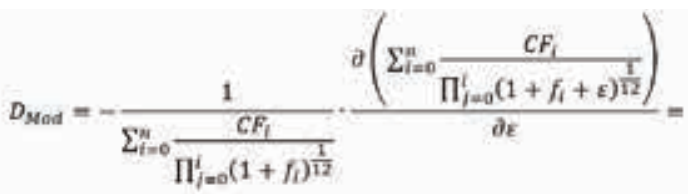

$$
=\frac{\sum_{i=0}^{n}\left[\left(\sum_{j=1}^{i} \frac{\frac{1}{12}}{\left(1+f_{i}\right)^{\frac{1}{12}}}\right) \cdot \frac{C F_{i}}{\prod_{j=0}^{i}\left(1+f_{i}\right)^{\frac{1}{12}}}\right]}{\sum_{i=0}^{n} \frac{C F_{i}}{\prod_{j=0}^{i}\left(1+f_{i}\right)^{\frac{1}{12}}}}=\frac{\sum_{i=0}^{n}\left[\hat{t}_{i} \cdot \frac{C F_{i}}{\prod_{j=0}^{i}\left(1+f_{i}\right)^{\frac{1}{12}}}\right]}{\sum_{i=0}^{n} \frac{C F_{i}}{\prod_{j=0}^{i}(1+f)^{\frac{1}{12}}}}
$$

ahol

$$
\hat{t}_{i}=\sum_{j=1}^{i} \frac{\frac{1}{12}}{(1+f)^{\frac{1}{12}}}
$$

mely rekurzívan (29) szerint könnyen számolható: $\quad \hat{t}_{0}=0 \quad \hat{t}_{i}=\hat{t}_{i-1}+\frac{\frac{1}{12}}{\left(1+f_{i}\right)^{\frac{1}{12}}}$

Mindkét esetben a Macaulay Duration formulához nagyon hasonló képlethez jutunk, pusztán a súlyozandó időpontértékeket kell egy módosított értékre cserélni. A két eltolás eredménye is nagyon hasonló, ami érthető, ha jobban megnézzük, hogy mire cseréljük a képletben az idő változót. A forward eltolás esetében a diszkontráták számtani közepe, míg a spot eltolás esetében a diszkontráták mértani közepe ${ }^{11}$ az, amivel korrekciós tényezőként kell szorozni az idő változóját. Ezek a diszkontráták mind nagyon közel vannak 1-hez, és a számtani közepük a mértani közepükhöz nagyon közel helyezkedik el. 


\section{Duration különbség (gap) minimalizálása}

A duration alkalmazása az eszköz-forrás illesztési vizsgálatokban logikus, hiszen ha szinkronba hozzuk az eszközeink kifutási ütemét a kötelezettségeink kifutási ütemével, akkor a két oldal átlagos kifutási ideje nagyon közel kell, hogy kerüljön egymáshoz, így a Macualay Durationok különbsége jó indikátora lehet a szinkronizálási törekvéseink sikerességének.

A Módosított Duration az eddigi képletekben csupán egy átlagos diszkontrátával való megszorzásban különbözik a Macaulay Durationtól. Így elvileg a Módosított Durationok különbsége is ugyanúgy jó indikátor lehet a likviditási különbségeknek. Később látni fogjuk, hogy ez a biztosítási kötelezettségek esetében nem lesz igaz, és az a gyakorlat, hogy az átlagos futamidőt kifejező Macaulay Duration helyett a kamatláb-érzékenységet mutató Módosított Durationt alkalmazzák a likviditási különbségek figyelésére, kimondottan hibás gyakorlat, és bizonyos esetekben még hibás üzleti döntésekhez is vezethet.

Nem szabad megfeledkeznünk az átlagmutatók hátrányáról. Kényelmes dolog, ha egyetlen átlagszámba tömörítjük a likviditás helyességének mérését, de tudjuk, hogy attól, hogy a kifutási ütemezés átlagos értéke nagyon közel van egymáshoz, még nem feltétlenül jelenti azt, hogy a két oldal kifutási üteme jól illeszkedne egymáshoz. Ezt a problémát mutatja a 3. ábra.

3. ábra: Példa arra, amikor az átlag azonos, de nincs illeszkedés

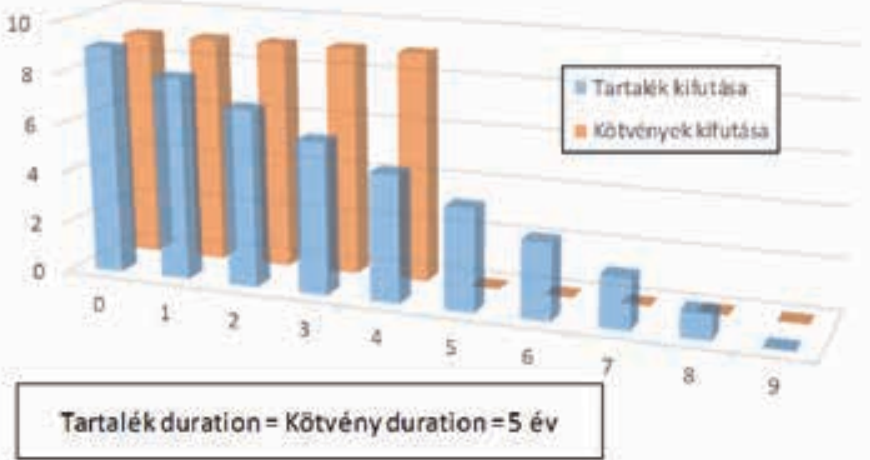

Forrás: Saját szerkesztés

A 3. ábra példája ${ }^{12}$ - ahol az első négy évben komoly likviditási gondok jelentkeznek ${ }^{13}$ - jól mutatja, hogy önmagában a duration különbség (gap) minimalizálás még messze nem elegendő a likviditási problémák megoldására. Legjobb megnézni a teljes kifutási idő ütemezését, ha pedig azt már megnézzük, akkor teljesen felesleges az átlagos kifutási időt nézegetni. Hiába egyszerűbb ugyan maguknak a kifutásoknak a vizuális megtekintése és illesztése, a piaci gyakorlat nem tudott elszakadni a durationok kiszámításától és alkalmazásától.
A Módosított Duration általánosítása egy sokkal bonyolultabb, sokkal több háttérszámítással előállítható mutatószám-sorozat a Kulcs-ráta (Key-rate) Duration. Annyiban fejlesztették tovább a Módosított Durationt, hogy nem a teljes hozamgörbe eltolásából fakadó érzékenységet vizsgálják, hanem csak egyes időszakaszokban mozdítják el a hozamgörbét ${ }^{14}$, így láthatóvá válnak azon időszakaszok, ahol a pénzmozgás-ütemezések nagyon nagy különbségeket mutatnak. A Kulcs-ráta Duration alkalmazása bonyolult, és mivel a kamatláb-érzékenységen keresztül mutatja a pénzmozgás eltéréseit, látni fogjuk a következő példából, hogy a biztosítási portfóliók esetében egyáltalán nem biztos, hogy meg is fogja mutatni a pénzmozgás-különbségeket.

\section{A jövőbeli kamatoktól függő biztosítási kötelezettségek Módosított Durationja}

Eddig a Módosított Duration kiszámításában a deriválásnál feltételeztük, hogy a pénzmozgás független a hozamgörbétől. A korábbi képletek jól alkalmazhatók fix kamatozású kötvény portfóliók Módosított Durationjainak kiszámítására. Viszont a biztosítási kötelezettségek tekintetében ez a feltételezés legtöbbször nem teljesül ${ }^{15}$. Ezen esetekre nincs általánosan alkalmazható képlet, rendszerint a Módosított Duration a hozamgörbe tényleges kismértékű eltolásával, a kötelezettségek ismételt kiszámításával becsülhető meg. A kötelezettségek kamatfüggősége sokféle okból fakadhat:

(többlet)hozam-visszaadásból eredően, amennyiben szükséges a jövőben befektetések vásárlása (életbiztosítás),

infláció és kamatkörnyezet kapcsolatán keresztül az inflációtól függő kártérítések szintén közvetett módon függhetnek a jövőbeli kamatoktól, kamatkörnyezettől (jellemzően nem-életbiztosítás),

infláció és kamatkörnyezet kapcsolatán keresztül az inflációtól függő költségek - melyekre költségtartalékot képeznek a biztosítók - szintén közvetett módon függhetnek a jövőbeli kamatoktól, kamatkörnyezettól (élet és nem-életbiztosítás is),

a biztosítási kötelezettségekre képzett tartalékok tartalmazhatnak tartalékcsökkentő hatású jövőbeli díjbevételeket is figyelembe vevő pénzmozgás elemeket. A biztosítási díjakat számos konstrukcióban akár inflációtól is függő módon emelni/indexálni szokták, így közvetett módon ezen jövőbeli pénzmozgás elemek is függhetnek a hozamgörbétől (élet és nem-életbiztosítás is).

Amennyiben minél pontosabban szeretnénk megbecsülni a vállalat piaci értékének kamatláb-érzékenységét, akkor a kockázatmentes kamatoktól való függőséget sokféle módon lehet beépíteni a kötelezettségek várható pénzmozgásait megbecsülő aktuáriusi modellekbe ${ }^{16}$. Ezeket most nem részletezzük, viszont egy nagyon leegyszerüsített példán keresztül bemutatjuk azt is, hogy milyen furcsaságokat tud produkálni a biztosítási kötelezettségek Módosított Durationja.

A gyakorlatban több, első látásra furcsa jelenséggel találkoztunk, melyekből érdemes levonni a szükséges következtetéseket, és elemzéseink során figyelembe venni őket. Igyekeztünk 
megtalálni a lehető legegyszerübb példákat, melyek már illusztrálják az adott jelenségeket. A következő példákban ezeket mutatjuk be.

\section{1. példa}

Biztosítási termékünk legyen a következő: a biztosítás tartama alatt a matematikai tartalék retrospektív alapon az aktuális lineárisan amortizált bruttó eszközértékkel egyenlö. Két év elteltével (a 0. időponthoz képest) kifizetjük a befektetések lineárisan amortizált bruttó értékének 90 százalékát. A 10 százalékos, kifizetéskori levonást nem érvényesítjük a matematikai tartalék értékében egészen az utolsó pillanatig. Hasonlóan tesszük ezt ahhoz, mint ahogy gyakran a visszavásárlási nyereséget, valamint még sok más jövőbeni veszteség és nyereség tételt sem veszünk figyelembe a matematikai tartalék értékének meghatározásakor. A második év végén a matematikai tartalék 90 százalékára csökkentett szolgáltatási összeget függőkártartalékba tesszük, és egyben a matematikai tartalékot nullára csökkentjük.

\section{A forward ráta legyen végig konstans:}

A 0. időpontban van egy befektetett eszközünk, amelynek 100 a könyv szerinti értéke. Az eszköz egy év múlva lejár, és fizet 105-öt (pl. zéró kupon kötvény). Egy év elteltével az újrabefektetéskor a kockázatmentes hozamgörbéből származtatott aktuális forward ráta mellett vásárolunk újra egy zéró kupon kötvényt.

A példát úgy alakítottuk ki, hogy likviditás szempontjából a pénzáramlások nem illeszkednek, újrabefektetésre van szükség. Az eszközök hamarabb lejárnak, mint amikor a kötelezettségoldali kifizetés megvalósul. Ez világosan látszik, ha összehasonlítjuk a tartalék cash-flow-kat az induló kötvények pénzmozgásaival.

Példánkban az induló maradék eszközportfólió nulla.

Készítsünk egy magyar számviteli szabályok szerinti mérleget a 0., 1. és 2. időpontban. A 0. időpontban saját tőke (maradék portfólió) nélkül, később az eszközök és források egyenlege adja (30)-ban a saját tőkét:

\begin{tabular}{lc|c} 
Idồ & Eszkōz & Forrás (számviteli tartalék) \\
\cline { 2 - 3 } & 100 & 100 \\
1 & 105 & 105 \\
2 & $105 \cdot(1+r)$ & $105+(1+r) \cdot 0,9$
\end{tabular}

Saját tōke
0
0
$105 \cdot(1+r) \cdot 0,1$

A piaci értékeléssel készített mérleg (leegyszerüsítve, például risk margin nélkül) pedig (31) alapján a következő:

\begin{tabular}{lc|c} 
Idö & Eszköz & Forrós (best estimate) \\
\cline { 2 - 3 } 0 & $105 /(1+r)$ & $105 /(1+r) \cdot 0,9$ \\
1 & 105 & $105 \cdot 0,9$ \\
2 & $105 \cdot(1+r)$ & $105 \cdot(1+r) \cdot 0,9$
\end{tabular}

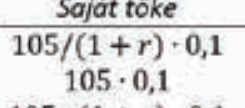

Ekkor a Módosított Duration az eszközoldalon a $D_{\text {Mod }}=-\frac{1}{\Sigma^{n}-d i s c\left(t_{i}\right) \cdot C F_{t}} \cdot \frac{\partial\left(\sum_{i=0}^{n} d i s c\left(t_{i}\right) C F_{i}\right)}{\partial r}$ képlet alapján a 0. időpontban (32) szerint:

$$
D_{\text {Mod }}=-\frac{1}{\left(\frac{105}{1+r}\right)} \cdot \frac{\partial\left(\frac{105}{1+r}\right)}{\partial r}=\frac{1}{\left(\frac{105}{1+r}\right)} \cdot \frac{105}{(1+r)^{2}}=\frac{1}{1+r}
$$

A forrásoldalon található kötelezettségekre is kiszámoljuk (33) alapján, és ugyanaz a Módosított Duration adódik a forrásoldalra is:

$$
D_{\text {Mod }}=-\frac{1}{\left(\frac{105}{1+r} \cdot 0,9\right)} \cdot \frac{\partial\left(\frac{105}{1+r} \cdot 0,9\right)}{\partial r}=\frac{1}{\left(\frac{105}{1+r} \cdot 0,9\right)} \cdot \frac{105 \cdot 0,9}{(1+r)^{2}}=\frac{1}{1+r}
$$

Így a Módosított Duration alapján tökéletes az illeszkedés (duration matching).

Mégis, ha egy kis kamatelmozdulást számolunk a tartalékhoz rendelt eszközökön és a kötelezettségeken, akkor elég hamar elmozdul egymástól a kettő. Emeljük meg az r értékét $\Delta \mathrm{r}$-rel.

Az eszközoldal értékének változását (34) mutatja:

$$
\frac{105}{1+r+\Delta r}-\frac{105}{1+r}=-\frac{105 \cdot \Delta r}{(1+r+\Delta r) \cdot(1+r)}
$$

A forrásoldal változása (35)-ben látható:

$$
\frac{105 \cdot 0,9}{1+r+\Delta r}-\frac{105 \cdot 0,9}{1+r}=-\frac{105 \cdot 0,9 \cdot \Delta r}{(1+r+\Delta r) \cdot(1+r)}
$$

Példánkban az ellentmondás abból adódik, hogy az eszközök és kötelezettségek összerendelése nem a piaci értékük szerint történik, hanem a magyar számviteli szabályoknak megfelelő lineárisan amortizált bruttó eszközérték szerint. A piaci mérlegben viszont ugyanezen eszközök és kötelezettségek piaci értéke eltér egymástól. Így hiába azonos a kamatláb-érzékenységük, hiszen ha eltérő piaci értékek változnak ugyanakkora kamatláb-érzékenységgel, akkor megbomlik az egyensúly. 
Az ellentmondás teljesen megszünik, ha egymáshoz skálázzuk az eszközöket és forrásokat, és (36) szerint ún. Dollár Durationt számolunk:

$$
D_{\text {Dol }}=-\frac{\partial\left(\sum_{i=0}^{n} \operatorname{disc}\left(t_{i}\right) \cdot C F_{i}\right)}{\partial r}=D_{M o d} \cdot \sum_{i=0}^{n} \operatorname{disc}\left(t_{i}\right) \cdot C F_{i}
$$

A másik lehetőség, hogy a különböző mértékű piaci értékek átskálázását csak a különbség (duration gap) számításakor vesszük figyelembe (37):

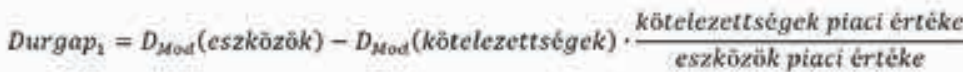

Szokás (38) szerinti formában is definiálni:

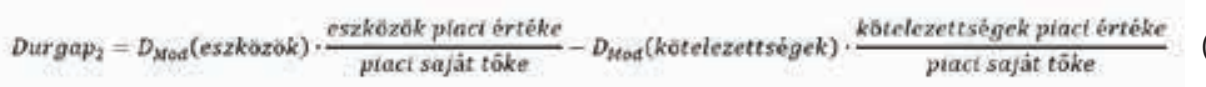

Ezzel a nagyon egyszerű példával azt is meg lehet mutatni, hogy ha a 0 . időpontban van saját tőkénk ${ }^{17}$, amit nem vonunk be a Módosított Duration számításába, akkor egy tökéletes duration matching mellett is - feltételezve, hogy a forward ráta és a sokkolt forward ráták is magasabbak, mint a technikai kamat - a kamatnövedés okoz nagyobb gondot a cégnek. Hiszen az eszközök értéke a kockázatmentes kamat növekedése hatására jobban fog csökkenni, mint a kötelezettségek piaci értéke.

Ez a jelenség elég gyakori a magyar viszonyok között.

\section{2. példa}

Vegyük az előző példát azzal, hogy egy $i=5$ százalékos technikai kamat mellett történik ugyanez. Készítsünk el ismét a magyar számviteli szabályok szerinti mérleget, amit (39) mutat:

\begin{tabular}{lc|c} 
Idö & Eszköz & Forrás (számviteli tartalék) \\
0 & 100 & 100 \\
1 & 105 & 105 \\
2 & $105 \cdot(1+r)$ & $105 \cdot \max (1+r, 1+i) \cdot 0.9$
\end{tabular}

A piaci mérleg pedig (40) alapján a következő:

\begin{tabular}{lc|c} 
Idö & Eszköz & Forrás (best estimate) \\
0 & $105 /(1+r)$ & $\frac{105 \cdot \max (1+r, 1+i) \cdot 0,9}{(1+r)^{2}}$ \\
1 & 105 & $\frac{105 \cdot \max (1+r, 1+i) \cdot 0,9}{1+r}$ \\
2 & $105 \cdot(1+r)$ & $105 \cdot \max (1+r, 1+i) \cdot 0,9$
\end{tabular}

Ekkor a Módosított Duration a forrásoldalon (41)-ből számítható

$\operatorname{ModD}(r)=\left\{\begin{array}{ll}-\frac{1}{\left(\frac{105 \cdot 0,9}{1+r}\right)} \cdot \frac{\partial\left(\frac{105 \cdot 0,9}{1+r}\right)}{\partial r} & \text {, ha } r>i \\ -\frac{1}{\left(\frac{105 \cdot 0,9 \cdot(1+i)}{(1+r)^{2}}\right)} \cdot \frac{\partial\left(\frac{105 \cdot 0,9 \cdot(1+i)}{(1+r)^{2}}\right)}{\partial r} & , \text { ha } r<i\end{array}= \begin{cases}\frac{1}{1+r}, & \text { ha } r>i \\ \frac{2}{1+r} & \text {, ha } r<i\end{cases}\right.$

Tehát, ha a forward ráta az 5 százalékos technikai kamat alá süllyed, akkor a kötelezettségoldal Módosított Durationja megduplázódik a 0 . időpontban. Ha a forward ráta 5 százalék felett van, akkor pedig éppen megegyezik a kötelezettségoldal az eszközoldal Módosított Durationjével. Ha pedig a forward ráta éppen megegyezik a technikai kamattal, akkor nem létezik derivált (csak jobbról és balról), és ezért nem létezik Módosított Duration sem. Ráadásul a jobb és bal oldali deriváltak meglehetősen távol vannak egymástól.

Ez pedig gyakorlati szempontból azt mutatja, hogy ha a hozamgörbe a technikai kamat közelében van, akkor a Módosított Duration - még ha létezik is - a gyakorlatban nem használható kamatláb-érzékenység vizsgálatára, mivel egy lokális érzékenységhez képest jelentősen változhat a tényleges kamatláb-érzékenység akár kismértékű kamatváltozás hatására is.

3. példa

Vegyük az előző példát két módosítással!

1. A kezdeti eszközünk nem pont az első év végén jár le:

Tegyük fel, hogy a meglévő eszköz nem az első év végén jár le, hanem az első és második év között lévő $(1+x)$ időpontban, és 100·1,05 $5^{(1+x)}$ összeget fizet lejáratkor. Ez a magyar számviteli szabályok szerinti mérlegben a lineáris amortizáció szerinti eszközértékelés miatt, az első év végén:

$$
100+\left(100 \cdot 1,05^{(1+x)}-100\right) \cdot \frac{1}{(1+x)}
$$

(42) szerinti értékkel szerepel.

$(1+x)$ időpontban a lejárat miatt felszabaduló pénzt úira befektetjük a forward rátán, úgy hogy ez pont a 2. év végén járjon le, így a 2. év végén (43)

$100 \cdot 1,05^{(1+x)} \cdot(1+r)^{(1-x)}$

(43)-ból számított értékü eszközünk lesz (mind a magyar számviteli szabályok szerinti, mind piaci mérlegben). 
Ekkor a szolgáltatási összeg (44)-ből adódik a 2. év végén (az adott eszköz 90\%-a, feltéve, hogy termeltünk legalább 5\%-nyi kamatot):

$$
100 \cdot \max \left(1,05^{(1+x)} \cdot(1+r)^{(1-x)} ; 1,05^{2}\right) \cdot 0,9
$$

2. Vannak ezen kívül olyan ügyféloldali befizetési és szolgáltatási elemek, amelyek nem kapcsolódnak a matematikai tartalékhoz:

Az eddigiek mellett van két díjbefizetés is az ügyfél részéről az 1. és 2 . időpontban 40-40 összegben, és van két szolgáltatási kifizetés is, ugyanazon időpontokban 20-20 összegben. Itt gondolhatunk arra, hogy kétszer 40 kiegészítő biztosítási díjat fizet az ügyfél, amiből rögtön ki is fizetünk 20 kárt, és marad 20 profitra mindkét időpontban. Ezek nem részei a matematikai tartalék képletének. De a piaci kötelezettség értékelésében részt vesznek. Az első év végén a 40-20 = 20 megmaradó összeget a biztosító az aktuális forward ráta szerint befekteti egyéves tartamra.

Készítsünk el ismét a magyar számviteli szabályok szerinti mérleget (45):

\begin{tabular}{cc|c} 
Ido & Eszköz & Forrds [szamviteli tartalék] \\
\hline 0 & 100 & 100 \\
\hline 1 & $100+\left(100 \cdot 1,05^{(1+x)}-100\right) \cdot \frac{1}{(1+x)}+20$ & $100+\left(100 \cdot 1,05^{(1+x)}-100\right) \cdot \frac{1}{(1+x)}$ \\
\hline 2 & $100 \cdot 1,05^{(1+x)} \cdot(1+r)^{(1-x)}+20 \cdot(1+r)+20$ & $100 \cdot \max \left(1,05^{(1+x)} \cdot(1+r)^{(1-x)} \cdot 1,05^{2}\right) \cdot 0,9$
\end{tabular}

A magyar számviteli szabályok szerinti saját tőke tehát a 0 . időpontban 0 . Az első év végén 20. A második év végén pedig:
$20 \cdot(2+\mathrm{r})+100 \cdot 1,05^{(1+\mathrm{x})} \cdot(1+\mathrm{r})^{(1-\mathrm{x})} \cdot 0,1$
ha $r \geq 5 \%$,

$20 \cdot(2+\mathrm{r})+100 \cdot 1,05^{(1+\mathrm{x})} \cdot(1+\mathrm{r})^{(1-\mathrm{x})}-100 \cdot 1,05^{2} \cdot 0,9$, ha $r<5 \%$.

A piaci mérleg pedig (48) alapján a következő:

\begin{tabular}{|c|c|c|}
\hline Id & Eszköz & Forrás (best estimate) \\
\hline & $\frac{\left(100 \cdot 1,05(1+x) \cdot(1+r)^{(1-x)}\right)}{(1+r)^{2}}$ & $\frac{100-\max \left(1.05^{(1+r)} \cdot(1+r)^{(1-x)} ; 1,05^{2}\right) \cdot 0,9-20 \cdot(2+r)}{(1+r)^{2}}$ \\
\hline 1 & $\frac{(1+r)^{2}}{\frac{\left(100+1,05^{(1+1)} \cdot(1+r)^{(1-r)}\right)}{(1+r)}+20}$ & $\frac{(1+r)^{2}}{\frac{100 \cdot \max \left(1,05^{(1+x)} \cdot(1+r)^{(1-x)} ; 1,05^{2}\right) \cdot 0,9-2}{(1+r)}}$ \\
\hline & $0 \cdot 1,05^{(t+x)} \cdot(1+r)^{(1-x)}+20 \cdot(2-$ & $100-\max \left(1.05^{(1+x)} \cdot(1+r)\right.$ \\
\hline
\end{tabular}

Nevezzük piaci saját tőkének (OF) a 0. időpontban a piaci mérleg eszköz- és forrásoldali különbségét:

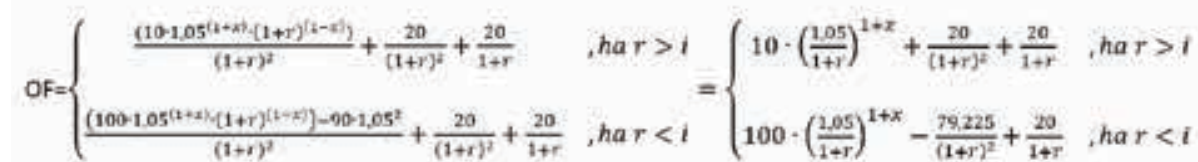

Könnyen belátható, hogy ennek a piaci saját tőkének a Módosított Durationja éppen a már korábban bemutatott átskálázott $\left(\right.$ durgap $\left._{2}\right)$ duration gap.

Látható, hogy a kötelezettség, az eszköz és a piaci saját tőke is deriválható jobbról és balról a forward ráta szerint, így a Módosított Duration is kiszámolható (persze csak jobbról és balról nézve, hiszen, ha $r=i$, akkor a jobb és bal oldali derivált nem azonos).

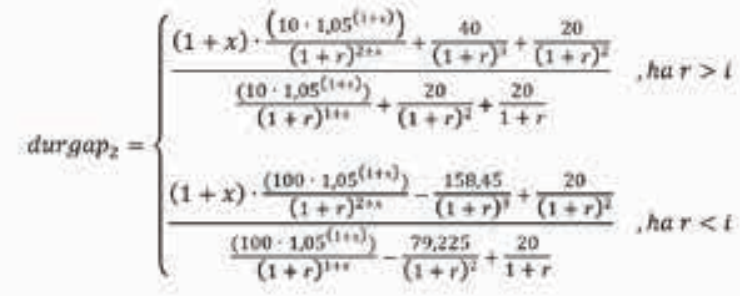

Az 4. ábrán kirajzoltuk, hogy $r=i=5$ esetén hogyan alakulnak ezek a Módosított Durationok a kezdetben meglévő eszközünk lejárati idejétől függően (amit 1-től 2-ig ábrázoltunk).

4. ábra: A különböző mérlegelemek Módosított Durationjai a kezdeti kötvények lejárati időpontjának függvényében

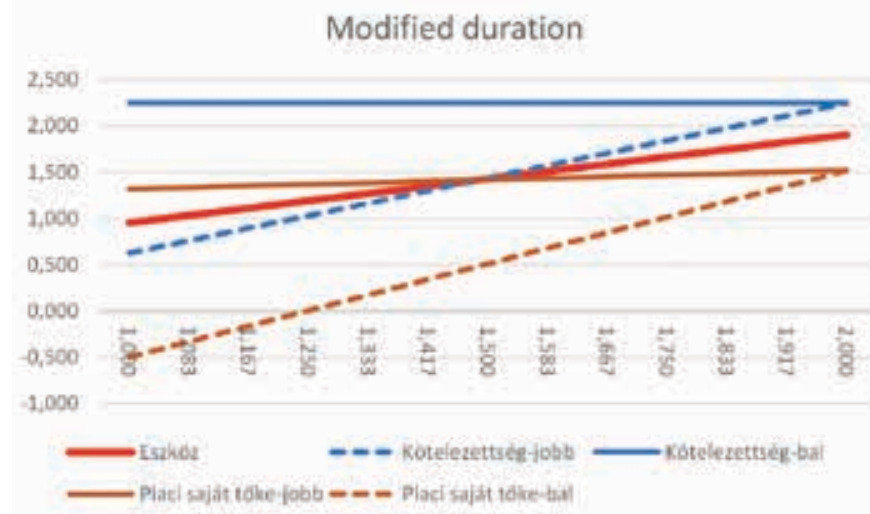

Forrás: Saját szerkesztés 
Ha a társaság kamatláb-érzékenységét akarjuk minimalizálni, akkor a piaci saját tőke Módosított Durationját kellene nullához közelíteni. Ezt balról (tehát ha még a technikai kamat alatt vagyunk kicsivel) úgy érhetjük el a diagram alapján, hogy a papír lejáratát 1,2 és 1,3 között állítjuk be. Megjegyezzük, hogy ugyan a kamatláb-érzékenység nulla ekkor, de likviditás szempontjából messze nincsenek a pénzmozgások összhangban.

Jobbról (tehát ha a technikai kamat felett vagyunk) úgy kerülhetünk legközelebb a nullához, ha a papír lejárata minimális (tehát itt 1), de így is nagyon messze van a nullától. A jobb oldali kamatláb-érzékenység igazából nem szüntethető meg az x megválasztásával.

Elöfordul, hogy megfeledkeznek arról, hogy az összehasonlított eszközök és a kötelezettségek piaci értéke nem azonos, és átskálázás nélkül hasonlítják a durationokat. Példánkban az előző ábrából látható, hogy így egészen más, helytelen eredményre jutnak. Ha az átskálázatlan durationokkal végzünk az eszközök és kötelezettségek között duration-illesztést, akkor - ha kicsivel a technikai kamat felett vagyunk - kb. másfél éves papírt kell vennünk. Ha kicsivel a technikai kamat alatt, akkor kétéveset (vagy akár hosszabbat) kell vásárolnunk. Holott a konstrukcióból világosan látszik, hogy ha két évnél hosszabb papírokat vásárolunk, akkor a 2. év végén ismét likviditási problémák fognak jelentkezni.

\section{4. példa}

Vegyük az előző példát $\mathrm{x}=1,1$ értékkel, és legyen $(1+r)$ egy picivel 1,05 feletti.

A diagramból látható, hogy ezen x és r érték mellett a saját tőke Módosított Durationja negatív. Az is látszik, hogy a tartalékok durationja alacsonyabb az eszközök durationjánál. Tehát akár a sima Módosított Durrationokat, akár a piaci értékekkel átsúlyozott Módosított Durationokat nézzük, mindkettő azt az üzenetet hordozza, hogy csökkenteni kellene az eszközök durationját, hogy a gapet csökkentsük. Vagyis x-et csökkentenünk kellene, hogy csökkentsük a kamatláb-érzékenységet. De világos a diagramból, hogy ez nem igaz, mert az x csökkentésével a gap mértéke növekedni fog. Nem beszélve arról, hogy likviditási szempontból is rossz irányba változtatnánk a kötvény lejárati pénzmozgását. Tehát ez a példa világosan mutatja, hogy a Módosított Duration könnyen téves üzleti döntésekhez is vezethet.

\section{5. példa}

A 3. példát azzal bővítjük, hogy az első és a második év végén a biztosító osztalékot fizet. Legyen $\mathrm{x}=1$, vagyis a kezdeti kötvényünk éppen a második év végén jár le. Az első év végén az osztalék mértéke 20 , a második év végén pedig az osztalék éppen annyi, amennyi a saját tőke mértéke. Vagyis a magyar számviteli mérlegben keletkező minden nyereséget az évek végén azonnal ki is fizetünk osztalékként.

Azt fogjuk bemutatni ezzel a példával, hogy az ALM likviditáselemzései során nem elegendő a tartalékok mögött lévő szerződéses kötelezettségek jövőbeli pénzmozgásaival foglalkoznunk, ugyanúgy vizsgálnunk kell a várható osztalékfizetés vagy tőketöltés miatt keletkező pénz- mozgások hatását is. Az ilyen jellegü pénzmozgások, melyek nem szerepelnek a piaci mérleg kötelezettségoldalának kiértékelésében, lehetetlenné teszik, hogy egyszerre optimalizáljuk a likviditást és a kamatláb-érzékenységet.

Példánkban a biztositót elhagyó, illetve bejövő pénzmozgások szempontjából tökéletes a likviditás illesztése. De a Módosított Duration számításánál a kötelezettségoldalon nem vesszük figyelembe az osztalékfizetést, így a számítások a következő módon alakulnak (kötelezettségoldal teljesen azonos a 3. példa kötelezettségoldalával):

A piaci mérleg a mindenkori osztalékfizetés után (51) szerint alakul:

\begin{tabular}{cc|c} 
Idö & Eszköz & Forrás (best estimate) \\
\hline 0 & $\frac{\left(100 \cdot 1,05^{2}\right)}{(1+r)^{2}}$ & $\frac{100 \cdot 1,05^{2} \cdot 0,9-20 \cdot(2+r)}{(1+r)^{2}}$ \\
\hline 1 & $\frac{\left(100 \cdot 1,05^{2}\right)}{(1+r)}$ & $\frac{100 \cdot 1,05^{2} \cdot 0,9-20 \cdot(2+r)}{(1+r)}$ \\
\hline 2 & $100 \cdot 1,05^{2} \cdot 0,9$ & $100 \cdot 1,05^{2} \cdot 0,9$
\end{tabular}

$$
\mathrm{OF}=\frac{\left(10 \cdot 1.05^{2}\right)}{(1+r)^{2}}+\frac{20}{(1+r)^{2}}+\frac{20}{1+r}
$$

$$
\text { durgap }_{2}=\frac{\frac{\left(20 \cdot 1,05^{2}\right)}{(1+r)^{3}}+\frac{40}{(1+r)^{3}}+\frac{20}{(1+r)^{2}}}{\frac{\left(10 \cdot 1,05^{2}\right)}{(1+r)^{2}}+\frac{20}{(1+r)^{2}}+\frac{20}{1+r}}
$$

Vagyis annak ellenére, hogy tökéletes a likviditásillesztés, soha nincs szabadon álló készpénz, és soha nem jelentkezik készpénzhiány, mégis egy pozitív duration gapet kapunk, vagyis a piaci mérlegünk alapján a vállalat piaci értéke érzékeny a kamatok változására. Mindez az ellentmondás abból adódik, hogy a kötelezettségoldali pénzmozgás esetében nem vettük figyelembe az osztalékfizetéseket.

Likviditás szempontjából a biztosítók a gyakorlatban ténylegesen szoktak foglalkozni az értékpapírok lejárati időzítésével, ahogy közeledik a soron következő osztalékfizetés időpontja. Hosszabb távon már ez kevésbé jellemző. Pedig középtávon a vállalat terveiben a várható osztalékfizetések ugyanúgy szerepelni szoktak, tehát léteznek egy éven túli várakozások is. De itt ütközünk bele abba a döntésbe, hogy az ALM során egy jövőbeli új szerzések nélküli kifutó vállalat pénzmozgásait vizsgáljuk. A vállalat tervei viszont rendszerint számolnak az új szerzésekkel. Egy új szerzések nélküli jövő várhatóan teljesen más osztalékfizetéseket tesz lehetővé, így a tervezés során használt osztalékmértékek kifutó vállalatot vizsgáló eszköz-forrás menedzsment során nem használhatók. Így kétféle megoldás választható: Elvégezzük az ALM elemzéseket nem kifutó, új szerzéseket is figyelembe vevő pénzmozgások esetén is, vagy az osztalékfizetéseket valahogy megbontjuk meglévő szerződésekre és a jövőbeli új szerzésekre jutó részekre. 


\section{Összefoglalás}

Azt tapasztaltuk, hogy biztonsággal nem alkalmazhatjuk a duration-illesztést (matchinget) kamatláb-érzékenység vizsgálatára, mivel jelentős ugrása van a Módosított Durationnek a technikai kamat környezetében. Ahol pedig nincs ugrása, de a kamat nagysága hozamvisszaadási tartományban van, ott a Módosított Duration nem mutatja a pénzmozgások likviditási különbségeit (gapjeit), és akár helytelen üzleti döntésekhez vezethet a használata

Ugyanezt a jelenséget mutatja a gyakorlatban egy komplex többlethozam-visszajuttatásos eszköz/forrás portfólió is, akkor is, ha a tartalékfedő eszközportfólión kívül is van eszköze a biztosítónak.

Rámutattunk arra, hogy az osztalékfizetés mint kötelezettségoldali pénzáramlás, eltérő likviditásoptimalizálási és kamatlábérzékenység-optimalizálási stratégiát indukálhat, vagyis gátolhatja, hogy egyszerre optimalizálhassuk mindkettőt.

A követhetőség miatt szándékosan a lehető legegyszerűbb példákat próbáltuk elóállítani, ami már mutatja azokat - a néha kontraintuitívnak tűnő - jelenségeket, amelyek megnehezítik az eszköz-forrás menedzsmentet egy magyarországi biztosítónál.

Számos további elemzési lehetőség van, melyekkel cikkünkben nem foglalkoztunk, például:

Miként kell kezelni, ha az eszközeink között nemcsak államkötvények, hanem annál jóval kockázatosabb, de emiatt jóval magasabb kamatokat ígérő eszközök is vannak?

Milyen elemzéseket érdemes készíteni, ha a tartalékok kifutásának a becslése nagyobb bizonytalanságot tartalmaz, emiatt gyakori, hogy a tényleges megvalósulás jelentősen eltér a korábban feltételezettől?

\section{HIVATKOZÁSOK}

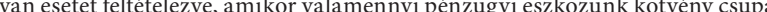

Realizálási nyereség/veszteség alatt azt értjük, hogy a kötvénynek a biztositó mérlegében kimutatottértéke különbözhet a kötvény piaci értékétől. Ha a köovén

Az adófizetéseket és a jutalekokat is a költségek között vesszük figyelembe.

'Ezen a ponton joggal felmerülhet az a kérdés, hogy miért kell eladni vagy vásárolni az eszközöket ahhoz, hogy a tartalékhoz rendelt porttolioba keruljenek. Hiszen egyszeruen à atsorolassal (vagyis a mozgatott papir értékének valtozasa nélkül) a tartalékokhoz nem rendelt értekpapirok kozzul vagy koze is megoldhato lenne. Az atsorolasnak azonban egyeb koovetkezmenyel is vannak, melyeknek további komoly etikai és pénzügyi következményei lehetnek. Egy korábbi időszakban vásárolt értékpapír könyv szerinti hozamai egy korabbi idopont kamatkondicioit tukkrözik, mely kondiciok a jelen idopontban mar nem feltetlenul erhetók el a piacon. Ha egy magasabb kamatkondiciokkal rendelkezo ertekpapirt elveszünk egy tartalekokhoz rendelt portfolioból,

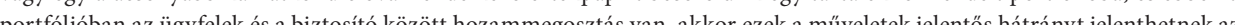

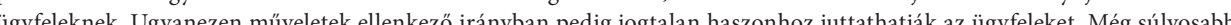

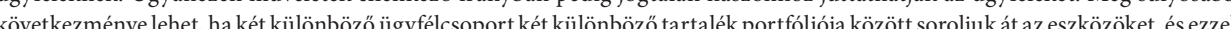
együtt hozamokat is átmozgatunk Éppen ezértcélszerü figvelembe venni azegy tartalékfedő portfóliókba tartozó szerződések tekintetében, hogy azonos portfólióba tartozó szerződések tartalékai között az eszközöo mozgatása ne vethessen fel etikai problémákat. Ahol pedig ez komoly etikai problémákat jelenthet, azokat elkülönülő tartalékfedő portfóliókba célszerü sorolni Az elsőként észrevehehtő különbség a szerzési költségek elhatárolásából fakad, hiszen gyakran előfordul, hogy a bejövố díbevéételek jelentősebb részét az elhatárolt szerzési költségek amortizációjának fedezetéül használiák el, és a dínak nem a teljes része fordítódik a tartalékképzés fedezetére. De ugyanígy viselkednek a különböző dijakat terhelő költségelvonások is. Nem beszélve tartalék képződik, mint ami a legjobb becslések alapján logikus lenne. Ha tovább boncolgatjuk a prospektív tartalékképzés vagy egyéb biztositástechnikai tartalékok számításának technikáit, akkor még inkább világossá válhat, hogy az adott időszaki díjbevétel, szolgáltatás és költségek egyenlege messze nem azonos a tartalékok változásával.

"Fle

ésre kerülnek a tartalékfedó

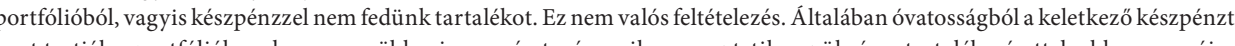
befektetik, vagy kivezetik. Azáltal, hogy automatikusan kivezetiük, az eszközportfólió méretének a csökkenése azonnal jelzi a keletkezett készpénzt vagy az újrabefektetési szüksé́gességet.

${ }^{8}$ Fontos kiemelni, hogy a kötvény lejáratával vagy a kuponfizetéssel keletkező készpénztáltalában bent szokták tartani a tartalékfedó portfólióban, és amint lehetöség nýlik rá, ismét befektetésre váltják. Ebből kifolyólag kétfajta befektetési tranzakció szokott megvalósulni, vagy a portfólión belül keletkezett készpénzt fektetik be újra, vagy pedig, mivel növelni kell a fedő portfólióban lévő eszközök volumenét, azt új befektetésekkel hajták végre. Hogy ne kelljen ezt a kétféle befektetést megkülönböztetnünk, a cikkünkben azt a megoldasst valaszztottuk, hogy a fedo portfolioban lejajattal vagy kuponfizetéssel keletkezo keszpenzzt mindig a

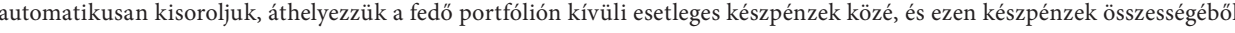
fizetjük az uj befekteteseseket, melyek a fedo porttolioba kerülnek. Kesspénzt a fedo porttolioban cikkunk sorann nem tartunk. 'Legfeljebb kompozit biztositó esetében találkozhatunk maradékportfólió-elkülönitéssel, de ott is csak az élet és a nem-élet terület közötti elkülönités létezik.

devizakitettségek összehangolására - mely szintén az ALM tevékenységek közé szokott sorolódni - cikkünkben nem térünk ki, feltételezzük, hogy egyetlen devizanemmel kell foglalkoznunk.

A

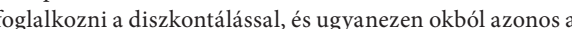

${ }^{3}$ A kötvényeket lejáratuk előtt kell majd eladni a jövőben, viszont az bizonytalan, hogy milyen áron fogjuk tudni értékesíteni öket.

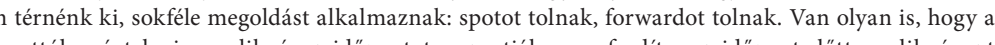
követően megtartiák az eredeti forward értékeket.

Az eszközök tekintetében is elôfordul a kockázatmentes hozamgörbétől való függés, például a változó kamatozású kötvények esetében, ahol rendszerint a Módositott Durationt a következő kuponfizetésig hátralévő idővel szokták becsülni. Ezekre az esetekre most nem térünk ki részletesen.

${ }^{16}$ Amennyiben viszonylag egyszerü függvény a kamattól való függés, akkor vehetü̈k a fáradságot, hogy a deriválás analitikus levezetésével zárt formulat alkossunk a Modositott Duration kiszámitására, mellyel nagyon sok aktuáriusi modellfuttatási idố megspórolhato. Am a gyakorlatban ez a függvénykapcsolat legtobbszor nem túl egyszerü.

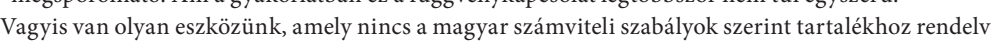

\section{IRODALOMJEGYZÉK}

Investopedia: Advanced Bond Concepts Online: http://www.investopedia.com/university/advancedbond/ Letöltés ideje 2017.02.06.

Online: https//en wikipedia org/wiki/Bond_duration

Letöltés ideje 2017.02.06

Casualty Actuarial Society: The Duration of Liabilities with $n$ terest Sinsitive Cash Flows

Online: http://www.casact.org/library/00pcas/gordarcy.pdf

Onliné http:// WWW.casact.
Letöltés ideje 2017.02.06. 